\title{
JUURNAL.RU
}

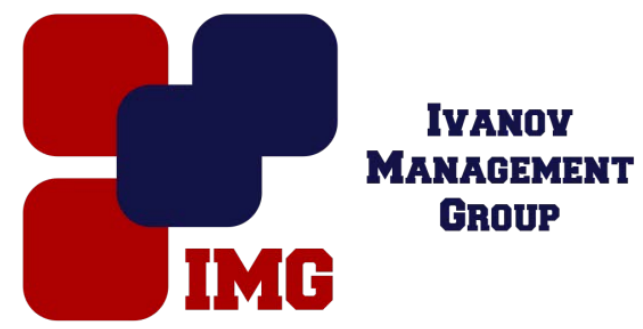

\author{
Мельник Т. Е., Ломакин Д. Е., Лебедева Е. В. \\ Орловский государственный университет имени И.С. Тургенева \\ Орел, Россия
}

doi: 10.18411/lj-31-03-2017-1-14

idsp 000001:lj-31-03-2017-1-14

\section{Направления повышения эффективностифункционирования трудовых ресурсов}

\section{Аннотация}

В статье рассматриваются различные подходы к повышению эффективности функционирования трудовых ресурсов через систему мотивации. Анализируются мнения разных ученых относительно методов и мероприятий по материальному и нематериальному стимулированиюсотрудников предприятий.

Ключевые слова: мотивация, трудовые ресурсы, стимулирование, трудовая деятельность, моральная мотивация, материальная мотивация.

В условиях рыночных отношений эффективное использование трудовых ресурсов предприятия становится непременным условием завоевания лидирующих позиций на рынке. Чем эффективнее работает коллектив предприятия, тем выше производительность труда, а, соответственно, и прибыль. Производительность труда зависит от многих факторов, в том числе и от качества работы сотрудников. Естественно, возникает вопрос: как стимулировать людей работать лучше.

Известно, что в основе любой деятельности лежит мотивация, которая представляет собой процесс побуждения себя и других к деятельности для достижения личных целей и целей организации. Именно мотивация определяет то, в какой степени человек реализует свой профессиональный потенциал на работе. Целью исследования является поиск новых приемов, методов и технологий мотивации трудовых ресурсов предприятия.

Ряд исследователей считают, что в наше время для многих людей труд рассматривается лишь как средство заработка, однако предполагается, что потребность в заработке для человека будет расти до определенного предела, после которого деньги станут условием нормального психологического состояния. После этого доминирующими станут потребности в творчестве, достижении успеха и другое[6]. 
КогдинА. А. в своей статьеговорит о том, что согласно последним исследованиям, доход, материальное стимулирование остается ключевым фактором заинтересованности сотрудников [3].Более того, опрос, проведенный кадровым агентством «KellyServices» в ряде стран, также показал, что основная рабочая мотивация россиян - зарплата, ее назвали $37 \%$ сотрудников [5].

Материальная мотивация, по мнению ЕвпловойЕ. В., делится на два типа:материальная-денежная и материальная-неденежная. К первой относится повышение заработной платы, премии, 13-ая зарплата и т.д. Ко второму типу относится, например, оплата бензина или проезда, путевки, подарки и т.д., т.е. всё то, на что компания тратит деньги, однако сотрудник получает не денежные средства, а материальные ценности.

При этом необходимо понимать, что не все способы экономического поощрения могут оказать мотивационное воздействие на сотрудников.

Одним из самых распространенных и эффективных способов экономического поощрения является премия. Задача руководителя, в случае применения экономической мотивации, заключается в разработке премиальной схемы выплат за производительность, качество выполнения задания, скорость выполнения задания и т.д.[1].

Как определить какие мотивирующие стимулы нужно применить к работнику, чтобы он работал лучше? ТрубниковаВ. В. и Пугач С. П. считают, что, исходя из уже существующих потребностей работника, определяются методы мотивирования, применяемые к нему. При изменении потребностей меняются и приемы. Удовлетворение одних потребностей приводит в действие другие, тем самым возникает необходимость создания определенных слагаемых качества трудовой жизни. Все эти факторы имеют непосредственное влияние на работника, производительность и эффективность и, как следствие, результат его труда.

Задача руководителей заключается в выявлении потребностей, а после в создании условий для их удовлетворения путём достижения производственных целей. В полной мере опыт и знания, которыми обладает работник, можно использовать на благо предприятия лишь в том случае, когда у него существует определенные потребности, которые он может удовлетворить при помощи труда[6].

Несмотря на то, что главным фактором, заставляющим человека работать, является заработная плата, существует множество других факторов, побуждающих к труду. В настоящее время доля нематериальных факторов незначительна, но при должном мотивировании нематериальные ценности прочно войдут в мотивационное ядро человека, изменив его ценностные ориентации. Соответственно, структура мотивирующих потребностей может быть обусловлена не только условиями труда, уровнем образования, возрастом, но и другими факторами[5].

Повышению заинтересованности и производительности труда также будет способствовать изменение стиля руководства. ДистсфаноДж.утверждает, что применение преобразовательного стиля является наиболее эффективным. В его основе лежит поощрение творческого подхода к поставленным задачам, привлечение работников к обсуждению новых идей, создание команды, члены которой дополняют друг друга и прочее. Акцент на необходимость применения 
некоторых принципов данного стиля руководства делают также Бурмистров Л. и ТрифильцеваН., однако они определяют его как применение методов нематериального стимулирования[6].

К сожалению, современные управленцы, специалисты кадровых служб, специалисты по мотивации персонала незаслуженно недооценивают роль и значение нематериальной мотивации в общей системе мотивации персонала.

Моральная мотивация имеет большое значение и не требует крупных финансовых затрат. Так, по мнению ЕвпловойЕ. В., мощными моральными мотивирующими факторами являются: выполнение обещаний руководителя;признание значимости работника;постановка четких и понятных задач перед работниками;понимание работником своей роли в общем механизме предприятия;«прозрачность» в работе;доведение руководителем дел до логического завершения.

Еще одним важным нематериальным мотивирующим фактором является внимание. Оно может быть трех видов: нулевое, отрицательное, положительное. Мотивирующим фактором может быть только положительное внимание. Это внимание, которое руководители уделяют своим подчиненным в тот момент, когда они достигают успехов в работе [2].

У конкретного предприятия не может быть стандартного пакета стимулов. Стимулирование должно быть адресным, ориентированным на конкретного работника.В целом можно сформулировать ряд правил осуществления эффективной мотивации работников:

1. Мотивирование даёт результаты, когда подчиненные ощущают признание своего вклада в результаты работы. Обстановка и размер кабинета, участие в престижных конгрессах, функция представителя фирмы на важных переговорах, поездка за рубеж, неординарное обозначение должности - всё это подчеркивает положение сотрудника в глазах коллег и посторонних лиц.

2. Неожиданные, непредсказуемые и нерегулярные поощрения мотивируют лучше, чем прогнозируемые, когда они практически становятся неизменной частью заработной платы.

3. Положительное подкрепление результативнее отрицательного.

4. Подкрепление должно быть безотлагательным, что выражается в незамедлительной и справедливой реакции на действия сотрудников.

5. Сотрудников следует стимулировать по промежуточным достижениям, не дожидаясь завершения всей работы, так как большие успехи труднодостижимы и сравнительно редки. Поэтому положительную мотивацию желательно подкреплять через не слишком большие интервалы времени.

6. Важно дать сотрудникам почувствовать себя уверенно, поскольку того требует внутренняя потребность в самоутверждении. Успех влечет за собой успех[4].

Таким образом, именно мотивация определяет в какой степени человек реализует свой профессиональный потенциал на работе. Четкой грани между материальным и нематериальным стимулированием нет, и они постоянно переплетаются, а порой просто неразделимы. Условием эффективного использования трудовых ресурсов является умелое сочетание различных стимулов для организации максимально эффективной деятельности предприятий. 
Представленные мероприятия по повышению мотивации работников позволят повысить их заинтересованность и эффективность производства в целом [1].

\section{Литература}

1. Гнеденко Н. П. Повышение эффективности использования трудовых ресурсов нефтяной компании на основе стимулирования труда / Н.П. Гнеденко // Современные наукоемкие технологии. 2006. №5. С. 70-71.

2. Евплова Е.В. К вопросу о материальной и нематериальной мотивации / Е.В. Евплова // Перспективы науки и образования. 2013. №2. С. 104-108.

3. Когдин А. А. Мотивация и стимулирование трудовой деятельности в управлении персоналом / А.А. Когдин // Основы экономики, управления и права. 2012. №4.С.1214.

4. Корзенко Н.И. Эффективные методы мотивации и стимулирования персонала / Н.И. Корзенко, М.Е. Зобнина // Вестник Челябинского государственного университета. 2012. №3(257). C. 66-69.

5. Скворцов В. Н. Трудовая мотивация работников в современных условиях / В. Н. Скворцов, У.А. Маклакова // Вестник Ленинградского государственного университета им. А.С. Пушкина. 2013. №1. С. 54-68.

6. Трубникова В.В. Проблема эффективного использования трудовых ресурсов в сельском хозяйстве / В.В. Трубникова, С.П. Пугач // Вестник Курской государственной сельскохозяйственной академии. 2013. №4. С. 14-17. 